\title{
NOTE
}

\section{Independent introduction of Bonamia ostreae, a parasite of Ostrea edulis, to Spain}

\author{
J. Cigarríáa ${ }^{1, *}$, R. Elston ${ }^{2}$ \\ ${ }^{1}$ Area de Zoología. Dpto. BOS, Universidad de Oviedo, E-33071 Asturies, Spain \\ ${ }^{2}$ Pacific Shellfish Institute, PO Box 687, Carlsborg, Washington 98382, USA
}

ABSTRACT: Records from oyster growers in Asturies, northern Spain, suggest that the introduction of Bonamia ostreae in Europe had at lodst 2 foci of infection: Brittany (France) and Asturies (Spain).

KEY WORDS: Bonamia ostreae - Ostrea edulis European flat oyster Bonamiasis

Katkansky et al. (1969) described a 'microcell' disease in the European flat oyster Ostrea edulis L. from California. The parasite, Bonamia ostreae, was subsequently recognized in Europe and described. Elston et al. (1986) traced the introduction of $B$. ostreae from California to France, where it had been recognized as a new serious disease in 1979 (Comps et al. 1980). Subsequent to the introduction of $B$. ostreae into Europe, bonamiasis spread along the Atlantic coast of Europe causing serious losses of flat oysters (Van Banning 1982, Polanco et al. 1984)

In Asturies, northern Spain, intertidal oyster culture has been practised since the early 1970s. From 1973 to 1977 , more the 70 tonnes of French origin flat oyster seed (average size $1 \mathrm{~g}$ ) was imported, grown to a size of $10 \mathrm{~g}$, and planted on oyster culturing rafts in Galicia, northern Spain. According to files we researched from an oyster grower in northern Spain, about 150 tonnes of oyster seed (10 g in size) were tranplanted from Asturies to Galicia from 1973 to 1977, and an annual mortality rate of $25 \%$ was subsequently recorded from the seed oysters in the Eo estuary. Further research of files from Asturies revealed invoices, air consignment records and certificates of origin which indicated the importation of seed from B. ostreae infected areas in California. According to these records, between 1977 and 1978, 3 million flat oyster seed were imported to

•E-mail: cigarria@sci.cpd uniovi.es
Asturies from California. In 1977, 1 million California oyster seed planted in March showed a $30 \%$ cumulative mortality by December. In 1978, 2 million California oysters planted in May showed $80 \%$ cumulative mortality by November Between 1977 and 1978, flat oysters of French origin in the same area had a low annual mortality rate (30\%). After 1978 , both California origin and French origin oysters showed annual mortality rates of 70 to $80 \%$ with peak mortality in the summer months. By 1980, flat oyster culture had nearly disappeared from Spain. The losses were attributed to infection by $B$. ostreae (Polanco et al. 1984, Montes \& Meléndez 1987). The infection may still be prevalent since recent attempts to establish flat oyster culture in the Eo estuary resulted in an $80 \%$ mortality rate over 15 mo (Cigarría et al. 1995).

Previously, the spread of Bonamia ostreae in European flat oyster culture was believed to have initiated from an infection in Brittany, France, which occurred in the late 1970s. The records we discovered suggest that $B$. ostreae spread from 2 or more independently established foci of infection (Brittany and Asturies), rather than from a single introduction from Brittany.

\section{LITERATURE CITED}

Comps M. Tige G, Grizel H (1980) Etude ultrastructural d'un protiste parasite de l'huitre plate Ostrea edulis L. C R Acad Sci, Paris, Ser D 290:383-384

Cigarría J, Fernández JM, López M (1995) Viabilidad del cultivo de la ostra plana (Ostrea edulis L.) en la Ría del Eo (Asturies, N España). Iberus 13(2):1-8

Elston RA, Farley CA, Kent ML (1986) Occurrence and significance of bonamiasis in European flat oysters Ostrea edulss in North America. Dis Aquat Org 2:49-54

Katkansky SC, Dahlstrom WA, Warner RW (1969) Observations on survival and growth of the European flat oyster, Ostrea edulis, in California. Calif Dept Fish Game 55(1):69-74 
Montes J, Meléndez MI (1987) Données sur la parasitose de Bonamia ostreae chez l'huitre plate de Galice, cote nordouest de l'Espagne. Aquaculture 67:195-198

Polanco E, Montes J, Outon MJ, Meléndez MI (1984) Situation pathologique du stock d'huítres plates en Calice (Espagne) en relation avec Bonamia ostreae. Haliotis 14:91-95

Responsible Subject Editor: A. K. Sparks, Seattle, Washington, USA
Van Banning P (1982) Some aspects of the occurrence, importance and control of the oyster pathogen Bonamia ostreae in the Dutch oyster culture. In: Payne CC. Burges HD (eds) Proceedings of the International Colloquium on Invertebrate Pathology. XVth Annu Meet, Soc Invert Pathol, University of Sussex, Brighton, p 261-265

Manuscript first received: September 24, 1996

Revised version accepted: January 28, 1997 